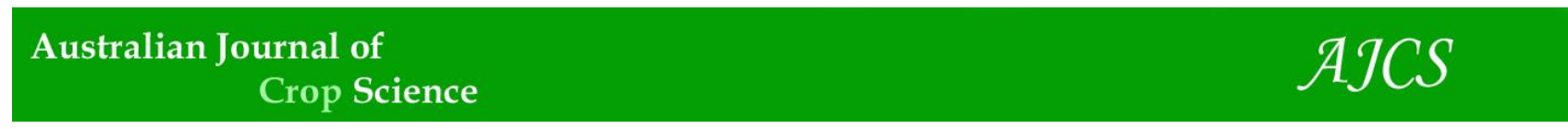

AJCS 11(02):134-141 (2017)

ISSN:1835-2707

doi: 10.21475/ajcs.17.11.02.p72

\title{
Nutritional composition of immature pods in selected cowpea [Vigna unguiculata (L.) Walp.] genotypes in South Africa
}

\author{
Abe Shegro Gerrano ${ }^{1 *}$, Willem Sternberg Jansen van Rensburg ${ }^{1}$, Patrick Olusanmi Adebola ${ }^{1,2}$ \\ ${ }^{1}$ Agricultural Research Council - Roodeplaat Vegetable and Ornamental Plants Institute, Private Bag X293, \\ Pretoria 0001, South Africa \\ ${ }^{2}$ Africa Rice Center (AfricaRice), C/o Central Agricultural Research Institute (CARI) Suakoko, Bong County, \\ PMB 3929, Monrovia, Liberia
}

*Corresponding author: agerrano@arc.agric.za

\begin{abstract}
Information on genetic variability among genotypes is useful in crop improvement programmes. The study was carried out to determine the variability of nutritional composition in the immature pods of selected cowpea genotypes for use in breeding for nutritional qualities. A total of 11 mineral elements $\left(\mathrm{K}^{+}, \mathrm{Ca}^{2+}, \mathrm{P}^{3-}, \mathrm{Mg}^{2+}, \mathrm{Na}^{+}, \mathrm{Fe}^{2+} \mathrm{Mn}^{2+}, \mathrm{B}^{3+}, \mathrm{Al}^{3+}, \mathrm{Zn}^{2+}, \mathrm{Cu}^{+}\right)$and total protein content were determined for the green immature pods of 22 cowpea genotypes collected from Nigeria and South Africa. The univariate analysis revealed significant differences among the genotypes for the traits evaluated. Genotype ITOOK-1060 has the highest value of $\mathrm{Mg}\left(4262.00 \mathrm{mg} \mathrm{kg}^{-1}\right), \mathrm{Na}\left(329.33 \mathrm{mg} \mathrm{kg}^{-1}\right) \mathrm{Mn}(47.72 \mathrm{mg} \mathrm{kg}-1), \mathrm{B}\left(14.31 \mathrm{mg} \mathrm{kg}^{-1}\right), \mathrm{Al}\left(78.61 \mathrm{mg} \mathrm{kg}^{-1}\right), \mathrm{Zn}(56.25$ $\left.\mathrm{mg} \mathrm{kg}^{-1}\right)$ and $\mathrm{Cu}\left(9.00 \mathrm{mg} \mathrm{kg}^{-1}\right)$. TVU-14196 has the highest values for $\mathrm{Fe}\left(97.78 \mathrm{mg} \mathrm{kg}^{-1}\right)$ while $98 \mathrm{~K}-5301$ has the highest values for $\mathrm{K}\left(24078.00 \mathrm{mg} \mathrm{kg}^{-1}\right), \mathrm{Ca}\left(8677.70 \mathrm{mg} \mathrm{kg}^{-1}\right), \mathrm{P}\left(5375.30 \mathrm{mg} \mathrm{kg}^{-1}\right)$ and protein $(28.54 \%)$. The multivariate analysis showed wide genetic variability among the genotypes which could be exploited in selecting suitable parents when breeding for nutritional qualities. High heritability estimates were also observed in most of the traits evaluated indicating potential genetic gain when breeding for these traits. The present study revealed the genetic potential of the genotypes studied and their importance for use in the breeding programme aimed towards combating nutritional deficiencies and food insecurity in South Africa.
\end{abstract}

Keywords: cowpea, genetic variability, heritability, immature pod, principal component analysis.

Abbreviations: ANOVA_Analysis of variance; ARC_Agricultural Research Council; GCV_Genotypic coefficient of variation; PCA_Principal component analysis; PC_principal component; PCV_Phenotypic coefficient of variation; $\sigma^{2} \mathrm{~g}$ _Genetic variance; MSg_Mean squares of genotype; MSe_Mean squares of error; $r \_n u m b e r$ of replications; $\sigma^{2} p \_$Phenotypic variance; $\sqrt{ } V g \_s q u a r e ~ r o o t$ of genetic variance; $\sqrt{ } \mathrm{V}$ __square root of phenotypic variance; $X \_$grand mean for the phenotypic traits; $h^{2}$ bs_Broad sense heritability.

\section{Introduction}

Cowpea is one of the most important indigenous crops in Southern Africa and is grown for its young leaves, succulent immature pods and dry seeds (Hall et al., 2003; Hazra et al., 2007). The crop can grow in low rainfall areas and improves the fertility of soils in marginal lands by providing ground cover and crop residues, fixing atmospheric nitrogen and suppressing weeds. Cowpea, thus, has the potential to be an ideal crop for production in drier regions, particularly in Africa. According to Phillips and McWatters (1991) it is the crop of rural Africa and very rich in protein, vitamins and minerals. Cooked cowpea fresh seeds and immature pods are relished by many consumers in different parts of the world and are sometimes preferred than the cooked dry seeds (Nielsen et al., 1997; Ahenkora et al., 1998; Timko et al., 2008). The pods are best when young and slender, and are eaten fresh or cooked, often cut into short sections and used in stir-fries or cooked salads. The pods are also a good source of protein, as well as vitamins and minerals including vitamins $\mathrm{A}$ and $\mathrm{C}$, folate and iron (Vaughan and Geissler, 2008). According to Welch and Johansen (2002), the crop has the potential of providing the nutritional requirements of developing countries, especially for women and children, as a cheap source of protein and an important source of iron.
Cowpea haulms are also fed to livestock as a nutritious fodder (Singh et al, 2003). In sub-Saharan Africa, micronutrient deficiency, usually referred to as 'hidden hunger', is also a major problem. Stunted growth and being underweight remain the most common nutritional disorders affecting young people in South Africa. Providing nutritious food for the poor and undernourished populations has been a major challenge for the developing world and acute shortage, unreliable supply, and elevated costs of protein-rich foods of animal origin in the developing and underdeveloped countries have resulted in the search for inexpensive and reliable alternative sources of minerals and proteins of plant origin (Bhat and Karim, 2009). Agronomic bio-fortification of locally consumed crops seems to be a plausible solution to this problem. Improvement of nutritional quality of cowpea genotypes is therefore important and will contribute to alleviating nutritional deficiency in South Africa. The information on the genetic variability of the nutritional composition of the immature pods in cowpea genotypes is an important and the first step towards the development of improved cultivars with higher nutritional content in breeding programmes. Due to cowpea's strategic significance in food, nutritional and income security in South Africa, research 
towards long-term genetic improvement is ongoing in the ARC, with the aim of generating cultivars with better yield potential and nutritional composition. It is believed that improving cowpea for nutritional value will greatly improve the diets of people affected by hunger and malnutrition. To this end, a large number of cowpea germplasm collected from different sources were maintained in the seed genebank of the $\mathrm{ARC}$ and are being evaluated. Information on the genetic heritability and genetic advance of the concentration of mineral elements and total protein content is also important for efficient and effective selection in our breeding programme. The current breeding effort involves evaluating the available genotypes for the concentration of mineral elements and total protein content. Hence, the objective of this study was to quantify and determine the variability of selected mineral elements and total protein content in the immature pods of cowpea genotypes grown in South Africa. The genotypic and phenotypic variances as well as the heritability estimates in the broad sense and genetic advance of the nutritional composition and total protein content were also determined.

\section{Results and Discussion}

\section{Analysis of variance for nutritional values}

Calcium, magnesium, phosphorus, potassium and sodium are the five major minerals for the human body. Other important trace elements consist of chromium, copper, iodine, iron, manganese, and zinc. Insufficient consumption of these nutrients could result in metabolic disorders, leading to sickness, poor health, impaired development and growth, particularly in children (Ramakrishnan et al., 1999; Branca and Ferrari, 2002; Welch and Graham, 2004). In the present study, eleven mineral elements consisting of macro $\left(\mathrm{K}^{+}\right.$, $\mathrm{Ca}^{2+}, \mathrm{P}^{3-}, \mathrm{Mg}^{2+}$ and $\left.\mathrm{Na}^{+}\right)$and micro $\left(\mathrm{Fe}^{2+}, \mathrm{Mn}^{2+}, \mathrm{B}^{3+}, \mathrm{Al}^{3+}\right.$, $\mathrm{Zn}^{2+}$, and $\mathrm{Cu}^{+}$) elements were quantified for their concentration in the immature pods of cowpea genotypes (Table 1). The mean squares from the univariate analysis of variance for the selected mineral elements and total protein content showed highly significant differences $(\mathrm{P} \leq 0.01)$ among the genotypes (Table 1). Potassium content of samples varied from 17074.00 to $24078.00 \mathrm{mg} \mathrm{kg}^{-1}$ and significantly higher mean values were recorded in genotypes 98K-5301 and ITOOK-1060 compared to the rest of the genotypes.The mean calcium content ranged between 2236.70 and $8677.70 \mathrm{mg} \mathrm{kg}^{-1}$ in genotype $98 \mathrm{~K}-5301$ and genotype Pan311, respectively. In a study of 20 cowpea landraces in Benin, Madode et al. (2012) reported calcium content variation of $700-1400 \mathrm{mg} \mathrm{kg}^{-1}$, while a range of 56$104 \mathrm{mg} \mathrm{kg}^{-1}$ and $37-54 \mathrm{mg} \mathrm{kg}^{-1}$ are reported for iron and zinc respectively. Similarly, the highest mean phosphorus content was recorded in genotype 98K-5301 with the concentration amount of $\left(5375.30 \mathrm{mg} \mathrm{kg}^{-1}\right)$, while the lowest mean value was obtained in genotypes IT845-2246 (3834.30 mg kg-1). Calcium and potassium plays a significant role in body metabolism. Calcium is an important element in enzyme activation and-functions as a constituent of bones and teeth, and is involved in the regulation of nerve and muscle function (Murray et al., 2000). Manganese, boron, aluminium, copper, iron and zinc are essential micronutrients involved in many metabolic processes and enzymatic activities (Van Gossum and Neve, 1998). Manganese is a component of many enzymes that includes mitochondrial superoxide dismutase and also activates other enzymes such as hydrolases, kinases and transferases (Reynolds et al., 1994). Results obtained in this study also revealed large variation in the concentration of these elements among the genotypes studied. For manganese the highest concentration was $47.72 \mathrm{mg} \mathrm{kg}^{-1}$ and was recorded in genotype ITOOK1060. This value was much higher than the values reported by Ano and Ubonchi (2008) for the vegetable cowpeas. Boron showed the highest concentration of $40.31 \mathrm{mg} \mathrm{kg}^{-1}$ in the genotype ITOOK-1060, while the lowest concentration $\left(21.29 \mathrm{mg} \mathrm{kg}^{-1}\right)$ was recorded in genotype Glenda. The highest concentration of aluminium was recorded in genotype ITOOK-1060 (78.61 mg kg-1), while the lowest concentration was found in genotype Bensogla. Zinc is involved in the metabolism of energy, proteins, carbohydrates, lipids and nucleic acids, and is one of the essential trace elements for tissue accretion (Zlotkin and Buchanan, 1988). It was also reported that zinc dependent enzymes are involved in macronutrient metabolism and cell replication (Arinola, 2008). The highest concentration of zinc was $56.25 \mathrm{mg} \mathrm{kg}$ 1in genotype ITOOK-1060, which was higher than the values reported by Ano and Ubonchi (2008) in Nigeria. The concentration of copper varied from 4.84 to $9.54 \mathrm{mg} \mathrm{kg}-1$ with the highest concentration recorded in the genotype IT845-2246. Iron is an essential trace element that plays an important role in red blood cell formation and its deficiency results in the reduction of red blood cells. In the present study, there was no significant difference in the Fe content (at both $\mathrm{P} \leq 0.01$ and $\mathrm{P} \leq 0.05$ ) of cowpea genotypes evaluated. However, the highest concentration was recorded in genotype TVU-14196 and was found to be the best source of iron among the genotypes, but far lower than the values reported by Ano and Ubonchi (2008) in Nigeria. According to Madode et al. (2012), the differences between the various studies could be attributed to varietal differences, but are more likely to result from differences in soil fertility. The variation of both micronutrients and macronutrients observed in the current study might be attributed to the differential ability of the genotypes to absorb the mineral elements from the soil and transport them into the plant system (Shegro et al., 2012). It might also be a function of the factor of soil type, soil texture, geographic locations where these genotypes are adapted to, and climatic conditions that prevailed during the growing season.

Protein energy malnutrition is the most lethal form (FAO, 2006) of malnutrition and affects every fourth child worldwide (WHO, 2006). A concerted effort is therefore required to combat this problem. This study showed that protein content from the immature cowpea pods ranged from 20.65 to $28.54 \%$, with highest value recorded in genotype 98K-5301. Duke (1981) reported that cowpea grains contain between 18 and $29 \%$ protein, with a potential for $35 \%$, depending on the variety. The overall mean value of $25.30 \%$ obtained in this study is higher than the values reported by (Hazra et al., 2001), but lower than the values reported by Ojimelukwe et al. (2014) in Nigeria. Yusuf et al. (2013) found $27.11 \%$ crude protein content in the young pods of cowpea in Nigeria. However, Ano and Ubonchi (2008) reported lower values of protein content (19.89 to 26.56\%) in vegetable cowpea genotypes in Nigeria as compared to this finding. According to Rangel et al. (2003), cowpea seed consists of about $25 \%$ protein and is low in anti-nutritional factors. This therefore points to $98 \mathrm{~K}-5301$, with $28.54 \%$ protein content, as a genotype of interest when breeding for higher protein content. According to Noubissié et al. (2011), cowpea genotypes are highly variable for seed protein. The trait is controlled predominantly by non-additive genes and 
Table 1. Mean values for selected mineral elements and total protein content in immature pods of cowpea genotypes.

\begin{tabular}{|c|c|c|c|c|c|c|c|c|c|c|c|c|c|}
\hline \multirow[b]{2}{*}{ No. } & \multirow[b]{2}{*}{ Genotypes } & \multicolumn{11}{|c|}{ Macro-and micro mineral elements $\left(\mathrm{m} \mathrm{kg}^{-1}\right)$} & \multirow[b]{2}{*}{ protein $(\%)$} \\
\hline & & $\mathrm{K}^{+}$ & $\mathrm{Ca}^{2+}$ & $\mathrm{P}^{3-}$ & $\mathrm{Mg}^{2+}$ & $\mathrm{Na}^{+}$ & $\mathrm{Fe}^{2+}$ & $\mathrm{Mn}^{2+}$ & $\mathrm{B}^{3+}$ & $\mathrm{Al}^{3+}$ & $\mathrm{Zn}^{2+}$ & $\mathrm{Cu}^{+}$ & \\
\hline 1 & Bechuana white & 21428.00 & 4090.70 & 4346.00 & 3337.00 & 318.40 & 72.85 & 32.28 & 25.93 & 26.61 & 40.29 & 7.30 & 23.62 \\
\hline 2 & Bensogla & 17074.00 & 3185.70 & 4145.70 & 3281.00 & 261.70 & 60.05 & 26.87 & 22.18 & 18.39 & 35.28 & 8.81 & 25.20 \\
\hline 3 & $\mathrm{CH} 14$ & 18397.00 & 3396.30 & 4213.30 & 3281.70 & 229.50 & 72.99 & 25.12 & 26.76 & 27.53 & 33.32 & 6.35 & 26.42 \\
\hline 4 & Encore & 21246.00 & 4777.70 & 4693.00 & 3709.30 & 241.53 & 73.28 & 37.87 & 26.69 & 25.56 & 39.67 & 6.86 & 23.92 \\
\hline 5 & Fahari & 19594.00 & 4970.00 & 4424.70 & 3925.30 & 236.23 & 60.28 & 34.84 & 23.04 & 26.95 & 33.87 & 5.71 & 26.01 \\
\hline 6 & Glenda & 18956.00 & 3227.30 & 4303.70 & 3321.00 & 137.00 & 64.34 & 27.46 & 21.29 & 24.17 & 37.51 & 5.99 & 24.50 \\
\hline 7 & Ngoji & 18409.00 & 3692.70 & 4543.00 & 3356.70 & 179.70 & 63.96 & 24.55 & 22.64 & 32.93 & 36.80 & 6.81 & 26.59 \\
\hline 8 & Mamlaka & 18757.00 & 3270.30 & 4622.00 & 3962.70 & 238.87 & 80.78 & 33.11 & 24.28 & 27.22 & 39.56 & 5.27 & 25.03 \\
\hline 9 & IT90K-59 & 18566.00 & 3261.30 & 4349.30 & 3984.70 & 223.50 & 69.53 & 24.65 & 24.85 & 25.59 & 40.00 & 6.89 & 24.46 \\
\hline 10 & IT90K-76 & 20518.00 & 4977.00 & 4818.00 & 3710.70 & 248.60 & 63.59 & 26.25 & 24.55 & 28.68 & 37.96 & 6.25 & 25.67 \\
\hline 11 & IT96D-602 & 22127.00 & 2395.30 & 4844.30 & 3641.70 & 261.10 & 70.41 & 34.06 & 28.64 & 35.04 & 40.50 & 4.84 & 25.41 \\
\hline 12 & Vuli & 17531.00 & 2636.30 & 4117.70 & 3243.00 & 282.80 & 64.18 & 28.70 & 23.29 & 28.72 & 34.92 & 5.48 & 24.69 \\
\hline 13 & IT $845-2246$ & 17684.00 & 6900.00 & 3834.30 & 2998.70 & 185.67 & 81.20 & 21.05 & 23.44 & 36.79 & 36.30 & 9.54 & 21.93 \\
\hline 14 & ITOOK-1217 & 21238.00 & 6280.00 & 48157.00 & 4078.00 & 219.70 & 76.75 & 34.02 & 32.36 & 30.69 & 39.57 & 6.13 & 26.14 \\
\hline 15 & $98 \mathrm{~K}-5301$ & 24078.00 & 8677.70 & 5375.30 & 4104.70 & 264.70 & 76.70 & 34.73 & 39.14 & 36.04 & 43.66 & 6.52 & 28.54 \\
\hline 16 & ITOOK-1060 & 22265.00 & 4501.70 & 5198.70 & 4262.00 & 329.33 & 70.20 & 47.72 & 40.31 & 78.61 & 56.25 & 9.00 & 26.32 \\
\hline 17 & TVU6345 & 18614.00 & 4518.70 & 4599.00 & 3598.00 & 157.63 & 77.02 & 26.58 & 29.02 & 21.28 & 38.72 & 7.04 & 26.42 \\
\hline 18 & TVU-14196 & 21784.00 & 3453.00 & 5034.70 & 4136.00 & 239.20 & 97.78 & 44.75 & 29.94 & 41.15 & 48.38 & 5.65 & 27.24 \\
\hline 19 & TVU13953 & 19673.00 & 4090.30 & 4702.70 & 3366.00 & 215.97 & 73.45 & 30.32 & 24.20 & 30.15 & 42.69 & 5.29 & 26.06 \\
\hline 20 & TVU12637 & 19859.00 & 3845.30 & 4507.70 & 3413.70 & 174.23 & 69.36 & 29.01 & 24.54 & 26.75 & 39.98 & 6.02 & 26.54 \\
\hline 21 & Pan311 & 17176.00 & 2236.70 & 3960.00 & 3278.70 & 215.23 & 72.31 & 25.32 & 23.53 & 26.40 & 36.67 & 5.93 & 20.65 \\
\hline \multirow[t]{7}{*}{22} & TVU11424 & 19386.00 & 4175.20 & 4113.70 & 2979.70 & 238.10 & 60.36 & 22.94 & 23.32 & 21.82 & 32.53 & 5.90 & 25.15 \\
\hline & Grand mean & 19743.74 & 4175.18 & 4525.56 & 3588.18 & 231.76 & 71.43 & 30.55 & 26.54 & 30.78 & 39.29 & 6.53 & 25.30 \\
\hline & $\mathrm{CV}$ & 9.79 & 11.52 & 9.70 & 12.54 & 7.39 & 19.91 & 5.11 & 19.77 & 15.07 & 12.95 & 14.15 & 8.75 \\
\hline & $\operatorname{LSD}(0.05)$ & 3184.54 & 792.55 & 723.65 & 741.29 & 28.20 & 23.44 & 2.57 & 8.65 & 7.64 & 8.38 & 1.52 & 3.65 \\
\hline & SED & 1578.00 & 392.72 & 358.59 & 367.32 & 13.98 & 11.61 & 1.27 & 4.28 & 3.79 & 4.15 & 0.75 & 1.81 \\
\hline & MSE & 3735136.89 & 231345.97 & 192875.20 & 202390.73 & 292.95 & 202.31 & 2.43 & 27.53 & 21.52 & 25.88 & 0.85 & 4.90 \\
\hline & MS genotypes & $10540924.50 * *$ & $6971695.90 * *$ & $468371.63^{* *}$ & $441978.82 * *$ & $6625.61 * *$ & $226.29^{\text {ns }}$ & $136.97 * *$ & 77.12 ** & $429.11 * *$ & $82.57 * *$ & $4.53 * *$ & $8.93 *$ \\
\hline
\end{tabular}

Table 2. Mean squares (genotype and error), variance components and broad-sense heritability of mineral elements and total protein content in immature pods of cowpea.

\begin{tabular}{|c|c|c|c|c|c|c|c|c|c|c|c|c|}
\hline \multirow[b]{2}{*}{ Genetic parameters } & \multicolumn{11}{|c|}{ Macro-and micro mineral elements ( $\left.\mathrm{mg} \mathrm{kg}^{-1}\right)$} & \multirow[b]{2}{*}{ protein $(\%)$} \\
\hline & $\mathrm{K}^{+}$ & $\mathrm{Ca}^{2+}$ & $\mathrm{P}^{3-}$ & $\mathrm{Mg}^{2+}$ & $\mathrm{Na}^{+}$ & $\mathrm{Fe}^{2+}$ & $\mathrm{Mn}^{2+}$ & $\mathrm{B}^{3+}$ & $\mathrm{Al}^{3+}$ & $\mathrm{Zn}^{2+}$ & $\mathrm{Cu}^{+}$ & \\
\hline GM & 19743.74 & 4175.18 & 4525.56 & 3588.18 & 231.76 & 71.43 & 30.55 & 26.54 & 30.78 & 39.29 & 6.53 & 25.30 \\
\hline $\mathrm{MSg}$ & 10540924.50 & 6971695.90 & 468371.63 & 441978.82 & 6625.61 & 226.29 & 136.97 & 77.12 & 429.11 & 82.57 & 4.53 & 8.93 \\
\hline MSe & 3735136.89 & 231345.97 & 192875.20 & 202390.73 & 292.95 & 202.31 & 2.43 & 27.53 & 21.52 & 25.88 & 0.85 & 4.90 \\
\hline$\sigma^{2} g$ & 2268595.87 & 2246783.31 & 91832.14 & 79862.70 & 2110.89 & 7.99 & 44.85 & 16.53 & 135.86 & 18.90 & 1.23 & 1.34 \\
\hline$\sigma^{2} p$ & 6003732.76 & 2478129.28 & 284707.34 & 282253.43 & 2403.84 & 210.30 & 47.28 & 44.06 & 157.38 & 44.78 & 2.08 & 6.24 \\
\hline GCV & 7.63 & 35.90 & 6.70 & 7.88 & 19.82 & 3.96 & 21.92 & 15.32 & 37.87 & 11.06 & 16.98 & 4.58 \\
\hline PCV & 12.41 & 37.70 & 11.79 & 14.81 & 21.16 & 20.30 & 22.51 & 25.01 & 40.76 & 17.03 & 22.09 & 9.87 \\
\hline $\mathrm{h}^{2} \mathrm{bs}(\%)$ & 37.79 & 90.66 & 32.25 & 28.29 & 87.81 & 3.80 & 94.86 & 37.52 & 86.02 & 42.21 & 59.13 & 21.47 \\
\hline
\end{tabular}

$\mathrm{GM}=$ grand mean; $\mathrm{MSg}=$ genotype mean squares, MSe=Error mean squares; $\sigma^{2} \mathrm{~g}=$ genotypic variance; $\sigma^{2} \mathrm{p}=$ phenotypic variance; $\mathrm{GCV}=$ genotypic coefficient of variation; PCV=phenotypic coefficient of variation; h2bs $(\%)=$ broad sense heritability 


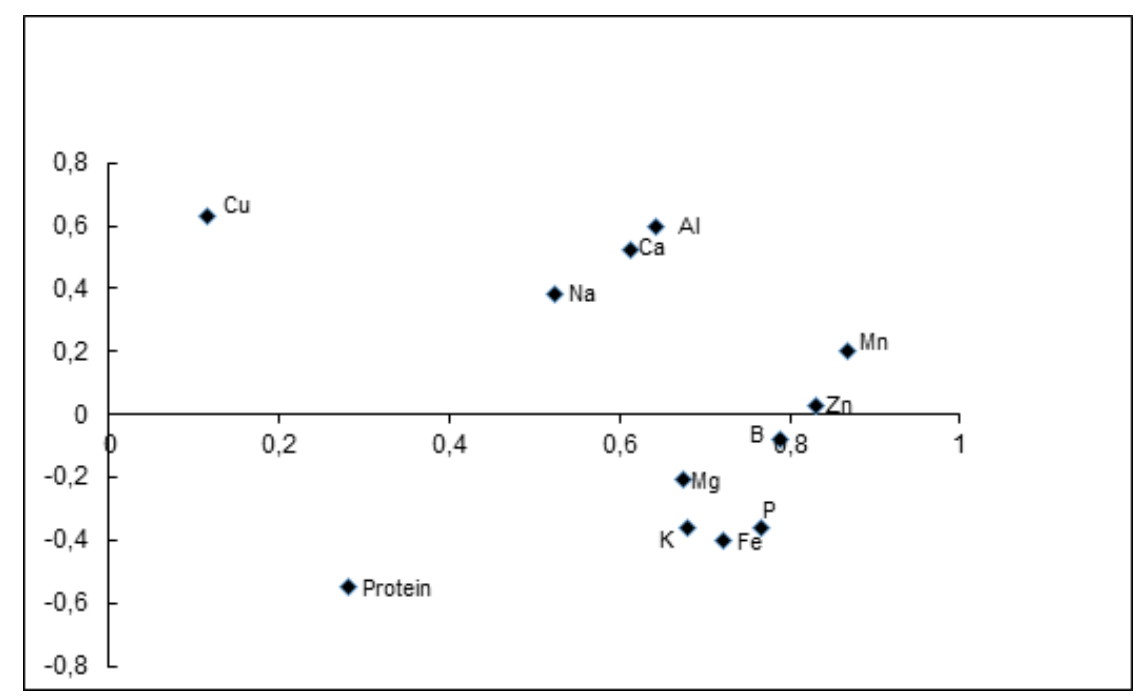

Fig 1. Principal component analysis loading plot of mineral elements and total protein content of 44 cowpea genotypes showing the relationships.

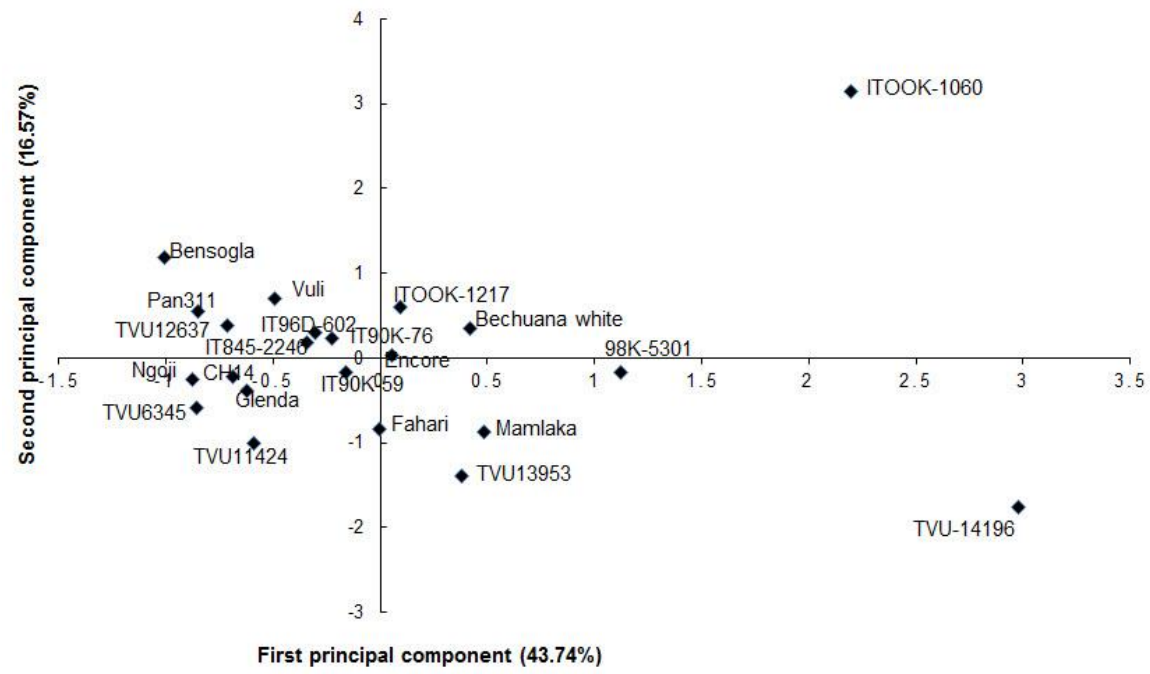

Fig 2. Principal component analysis score plot of the first and second principal components showing the spatial figuration of the 22 cowpea genotype based on the mineral elements and protein content of their immature pods.

systematic selection of parental lines is required for improvement of seed quality. In general, the trend of the concentration is $\mathrm{Ca}^{2+}>\mathrm{P}^{3-}>\mathrm{Mg}^{2+}>\mathrm{K}^{+}>\mathrm{Na}^{+}>\mathrm{Fe}^{2+}>\mathrm{Al}^{3+}$ $>\mathrm{Zn}^{2+}>\mathrm{Mn}^{2+}>\mathrm{B}^{3+}>\mathrm{Cu}^{+}$indicating that there is a high accumulation of macro elements in the immature pods of the genotypes studied. Ano and Ubonchi (2008) also reported variability of nutritional composition in the young pods of cowpea in Nigeria. Similarly, Ojimelukwe et al. (2014) reported variability in the concentration of mineral elements $\left(\mathrm{Fe}^{2+}, \mathrm{P}^{3-}, \mathrm{K}^{+}\right.$and $\left.\mathrm{Ca}^{2+}\right)$ and crude protein content in the immature pods of vegetable cowpea. Among the genotypes tested, 98K-5301 appeared to show the highest levels of $\mathrm{K}^{+}$, $\mathrm{Ca}^{2+}, \mathrm{P}^{3-}$ and protein contents. Genotype ITOOK-1060 revealed the highest concentration of $\mathrm{Mg}^{2+}, \mathrm{Na}^{+}, \mathrm{Mn}^{2+}, \mathrm{B}^{3+}$, $\mathrm{Al}^{3+}$ and $\mathrm{Zn}^{2+}$. These results indicate that the green pods of cowpea have relatively high and variable concentrations of total protein content, as well as macronutrients and micronutrients in the genotypes studied. This wide genetic variability can be exploited for use in cowpea breeding programmes cowpea for improved nutritional quality in South Africa. The results will specifically enable the selection of the best parental combination in our crossing programme. From the current study, it can be observed that the immature pods of cowpea are good sources of potassium, calcium, phosphorus, magnesium, iron and zinc, which would contribute to the alleviation of malnutrition when consumed.

\section{Variance components and heritability of nutritional values}

Estimates of genotypic and phenotypic coefficient of variations and broad sense heritability, as well as genetic variance and phenotypic variances are presented in Table 2 . Estimates of genetic variance and broad sense heritability are important biometrical genetic parameters for the selection of the parent lines from the plant population in breeding programmes (Ubi et al., 2001). The genetic coefficient of variation varied from 3.96 to $37.87 \%$, while the phenotypic coefficient of variation varied from 9.87 to $40.76 \%$. The values for genetic and phenotypic coefficients of variation were close, with little differences observed for some of the mineral elements, such as $\mathrm{Ca}^{2+}, \mathrm{Na}^{+}, \mathrm{Mn}^{2+}$ and $\mathrm{Al}^{3+}$, compared to $\mathrm{K}^{+}, \mathrm{P}^{3-}, \mathrm{Mg}^{2+}, \mathrm{Fe}^{2+}, \mathrm{B}^{3+}, \mathrm{Zn}^{2+}$, and $\mathrm{Cu}$, and protein content, indicating that there was very little environmental noise on the data collected for these mineral elements. This implies that the improvement of the genotypes 
Table 3. Principal component analysis for the concentration of selected mineral elements and total protein content in the immature pods of cowpea genotypes revealing eigenvalue, total variance, and eigenvector and contribution to total variation explained by the first four PC axes.

\begin{tabular}{|c|c|c|c|c|c|c|c|c|c|c|c|c|c|c|c|}
\hline \multirow[b]{2}{*}{ PC } & \multirow[b]{2}{*}{ Eigenvalue } & \multicolumn{2}{|l|}{ Total variance } & \multicolumn{12}{|c|}{ Eigenvectors } \\
\hline & & Individual (\%) & Cumulative (\%) & $\mathrm{K}^{+}$ & $\mathrm{Ca}^{2+}$ & $\mathrm{P}^{3-}$ & $\mathrm{Mg}^{2+}$ & $\mathrm{Na}^{+}$ & $\mathrm{Fe}^{2+}$ & $\mathrm{Mn}^{2+}$ & $\mathrm{B}^{+}$ & $\mathrm{Al}^{3+}$ & $\mathrm{Zn}^{2+}$ & $\mathrm{Cu}^{+}$ & Protein \\
\hline 1 & 5.25 & 43.74 & 43.74 & 0.30 & 0.27 & 0.34 & 0.29 & 0.23 & 0.32 & 0.38 & 0.34 & 0.28 & 0.36 & 0.05 & 0.12 \\
\hline 2 & 1.99 & 16.57 & 60.31 & -0.26 & 0.37 & -0.26 & -0.15 & 0.27 & -0.29 & 0.14 & -0.06 & 0.42 & 0.02 & 0.45 & -0.39 \\
\hline 3 & 1.23 & 10.27 & 70.58 & 0.17 & -0.46 & 0.23 & -0.24 & 0.28 & 0.28 & -0.11 & -0.05 & -0.25 & 0.23 & 0.37 & -0.48 \\
\hline 4 & 1.06 & 8.85 & 79.43 & 0.32 & 0.02 & -0.07 & 0.14 & 0.59 & -0.26 & 0.12 & 0.08 & -0.20 & -0.39 & -0.41 & -0.26 \\
\hline
\end{tabular}

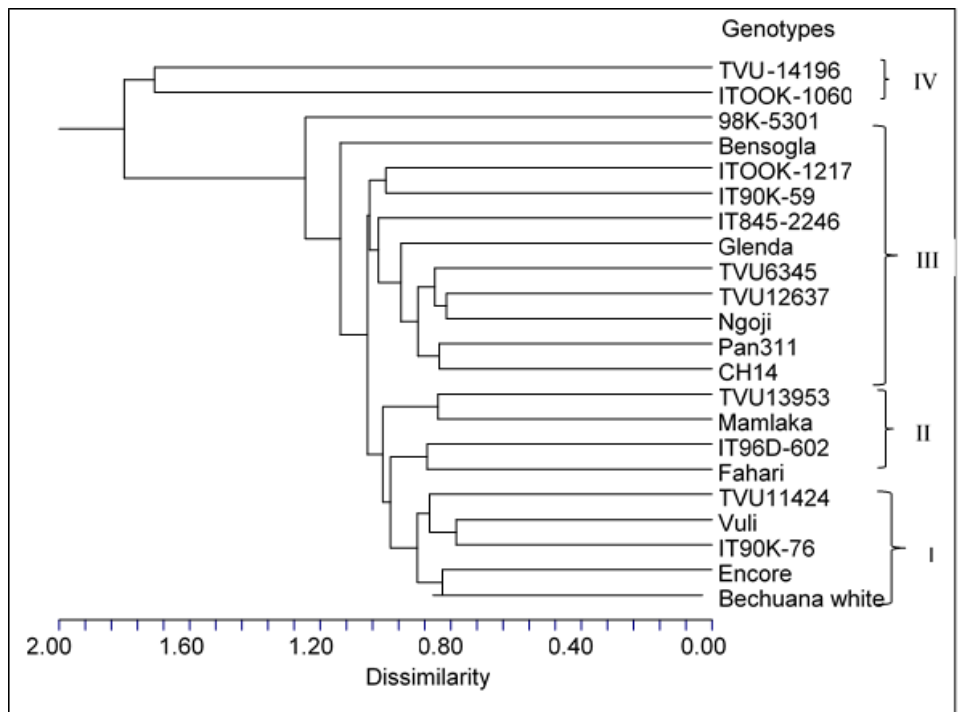

Fig 3. Dendrogram constructed based on mineral elements and protein contents data set, showing genetic distance and cluster groups among 22 cowpea genotypes.

Table 4. Cluster mean values for the concentration of selected mineral elements and total protein content in the immature pods of cowpea genotypes.

\begin{tabular}{|c|c|c|c|c|c|c|c|c|c|c|c|c|}
\hline \multirow[b]{2}{*}{ Cluster } & \multicolumn{12}{|c|}{ Concentration of mineral elements and protein content } \\
\hline & $\mathrm{K}^{+}$ & $\mathrm{Ca}^{2+}$ & $\mathrm{P}^{3-}$ & $\mathrm{Mg}^{2+}$ & $\mathrm{Na}^{+}$ & $\mathrm{Fe}^{2+}$ & $\mathrm{Mn}^{2+}$ & $\mathrm{B}^{3+}$ & $\mathrm{Al}^{3+}$ & $\mathrm{Zn}^{2+}$ & $\mathrm{Cu}^{+}$ & Protein \\
\hline I & 20021.80 & 4131.38 & 4417.68 & 3395.94 & 265.89 & 66.85 & 29.61 & 24.76 & 26.28 & 37.07 & 6.36 & 24.61 \\
\hline II & 20037.75 & 3681.48 & 4648.43 & 3723.93 & 238.04 & 71.23 & 34.84 & 23.04 & 26.95 & 39.16 & 5.28 & 25.63 \\
\hline III & 19095.55 & 4474.70 & 8362.57 & 3517.90 & 204.41 & 71.29 & 27.21 & 26.34 & 27.87 & 37.98 & 6.91 & 25.22 \\
\hline IV & 22024.50 & 3977.35 & 5116.70 & 4199.00 & 284.27 & 83.99 & 47.72 & 35.13 & 59.88 & 52.32 & 7.33 & 26.78 \\
\hline
\end{tabular}


for these traits can be achieved through evaluation and selection. Calcium, manganese and aluminium, on the other hand, had high values of genotypic and phenotypic coefficient of variations. A wider difference between GCV and PCV were also observed in $\mathrm{K}^{+}, \mathrm{P}^{3-}, \mathrm{Mg}^{2+}, \mathrm{Fe}^{2+}, \mathrm{B}^{3+}, \mathrm{Zn}^{2+}$ and protein traits, indicating that these mineral elements and protein traits were more influenced to a greater extent by environmental conditions. The heritability values ranged from $3.80-94.86 \%$. The mineral elements calcium, manganese, sodium and aluminium had high broad-sense heritability, indicating that the traits are considered as highly heritable and selection for these traits would be effective and efficient. High heritability estimates were also reported by Gerrano et al. (2015) in selected mineral elements of young leaves of cowpea genotypes in South Africa. According to Shukla et al. (2006) and Mobina et al. (2014), the genetic coefficient of variation together with heritability estimates provide a reliable and effective means of estimating the expected amount of improvement through selection of genotypes for traits of interest.

\section{Principal component analysis for the nutritional values}

Principal component analysis (PCA) was carried out to describe and understand the relationship amongst the 22 cowpea genotypes evaluated for nutritional traits and visualized by biplotting. The principal component analysis is shown in Table 3. The first four principal components (PCs) cumulatively explained $79.43 \%$ of the total variance among the cowpea genotypes. The first PC, with an eigenvalue of 5.25 , explained $43.74 \%$ of the total variation, mainly due to the variance dominated by $\mathrm{Mn}^{2+}, \mathrm{B}^{3+} \mathrm{Fe}^{2+}$ and $\mathrm{P}^{3-}$. The traits that contributed more to the second $\mathrm{PC}$, which accounted for $16.57 \%$ of the total variation, were $\mathrm{Cu}^{+}, \mathrm{Al}^{3+}$, protein, and $\mathrm{Ca}^{2+}$, with an eigenvalue of 1.99. PC1 and PC2, contributed a cumulative $60.31 \%$ in explaining the genetic variability present in the cowpea genotypes. PC3 and PC4, with eigenvalues of 1.23 and 1.06, respectively, had a combined contribution of $19.12 \%$ to the total variation. The results of this study indicated that $\mathrm{K}^{+}, \mathrm{Ca}^{2+}, \mathrm{P}^{3-,} \mathrm{Fe}^{2+}, \mathrm{Mn}^{2+}, \mathrm{B}^{3+}, \mathrm{Al}^{3+}$, $\mathrm{Zn}^{2+}, \mathrm{Cu}^{+}$and protein content are of primary importance in differentiating the genotypes. The relatively high eigenvectors observed in this study implies that the mineral elements with similar signs are highly correlated (Akinwale and Obisesan, 2012). Improvement of these traits can therefore be achieved simultaneously. Gerrano et al. (2015) also found similar patterns of nutritional traits and their association in the fresh leaves of cowpea genotypes in South Africa.

The PCA genotype-by-trait biplot clearly revealed the pattern of variation and relationship among the genotypes based on the concentration of mineral elements and protein content (Fig. 1 and Fig. 2). The principal component analysis grouped the mineral elements and protein into two different groups (Fig. 1). The mineral elements grouped into the top right and bottom right quadrants and were negatively correlated (Fig. 1). The biplot differentiated the genotypes based on their mineral and protein characteristics, as explained by the first and second principal dimensions (Fig. 2 ). The results clearly show the different genotypes on the score plot. This will assist in decision-making when selecting parental genotypes. The genotypes with a narrower distance between them in the score plot are genetically similar with regard to the evaluated traits, whereas those genotypes that are placed far from the origin of the quadrant are distinct. The results also revealed that the genotypes were scattered in the biplot, indicating wide genetic variability in respect to the traits evaluated. The genotypes in the top right quadrant were closely associated with the mineral elements such as $\mathrm{Cu}^{+}$, $\mathrm{Na}^{+}, \mathrm{Ca}^{2+} \mathrm{Al}^{3+} \mathrm{Zn}^{2+}$ and $\mathrm{Mn}^{2+}$ (Fig. 1). The right bottom quadrant comprised the genotypes that are closely related with the mineral elements such as $\mathrm{K}^{+}, \mathrm{Fe}^{2+,} \mathrm{Mg}^{2+} \mathrm{B}^{3+}$ and $\mathrm{P}^{3-}$, as well as protein. Those genotypes located on the top and bottom left quadrant were mostly associated with the low concentration of mineral elements and protein content. In the current study, the genotypes ITOOK-1060 and TVU-14196 stand out clearly as the most genetically divergent cowpea genotypes for the traits evaluated. This indicated that they might have a peculiar gene/allele that separated them from the group.

\section{Cluster analysis}

The segmentation analysis grouped the 22 cowpea genotypes into four distinct clusters based on the concentration of selected mineral elements and protein content, as determined in their immature green pods (Fig. 3), further attesting to the wide genetic differences observed amongst the genotypes for the traits evaluated. Table 4 shows the variability in the cowpea genotypes by summarizing the cluster means for the traits tested. The genotypes grouped within a cluster are closely related. Genotypes that were grouped in different clusters are assumed to be genetically far apart and could be used as parents in the breeding programme. Cluster I consists of five cowpea genotypes, namely, Bechuana white, Encore, IT90K-76, Vuli and TVU-11424, which was produced at a genetic distance of 0.92 , based on the concentration of $\mathrm{P}^{3-}, \mathrm{Mg}^{2+}, \mathrm{Fe}^{2+}, \mathrm{Al}^{3+}, \mathrm{Zn}^{2+}$ and protein content. When compared with the overall average of the cluster means, the lowest average concentration of mineral elements and total protein content were observed in this cluster. Cluster II was produced at a genetic distance of 1.04 and comprised genotypes Fahari, IT96D-602, Mamlaka and TVU13953, based on the concentration of $\mathrm{Fe}^{2+}$ and $\mathrm{Mn}^{2+}$. This group also clustered with the lowest content of $\mathrm{B}^{3+}$ and $\mathrm{Cu}^{+}$. The majority of the genotypes were grouped in cluster III, which was generated at a genetic distance of 1.28. These genotypes were clustered together due to their genetic similarity based on the concentration of $\mathrm{Ca}^{2+}$ and $\mathrm{P}^{3-}$. Genotypes in this group were further identified as containing, the lowest concentrations of $\mathrm{K}^{+}, \mathrm{Na}^{+}, \mathrm{Mn}^{2+}$. Two genotypes, namely, 98K-5301 and Bensogla were separated from their respective groups of genotypes in this cluster, mainly due to the concentration $\mathrm{K}^{+}$(Table 1). The fourth cluster consisted of only two genotypes produced at a genetic distance of 1.80 , namely, TVU-14196 and ITOOK-1060, based on the concentrations of $\mathrm{K}^{+}, \mathrm{Mg}^{2+}, \mathrm{Na}^{+}, \mathrm{Fe}^{2+}, \mathrm{Mn}^{2+}, \mathrm{B}^{3+}, \mathrm{Al}^{3+}, \mathrm{Zn}^{2+}$, $\mathrm{Cu}^{+}$and total protein content. These two genotypes were identified as a potential parental line for breeding, especially for high $\mathrm{Fe}^{2+}$ and $\mathrm{Zn}^{2+}$ concentrations. A dendrogram showing the relationships amongst 11 cowpea genotypes, based on their seed yields and its components, was reported by Amany and Hoda (2016), which divided the genotypes into four different sub-groups. Gerrano et al. (2015) reported the clustering of different cowpea genotypes based on the concentration of mineral elements and protein content in fresh leaves of cowpea genotypes in South Africa. This is the first report to show the spatial distribution of cowpea genotypes using mineral elements and protein concentrations of the green immature pods.

The information generated from this study therefore, will be very useful for breeders looking to identify potential parental lines for use in breeding programmes targeted towards nutritional quality improvement under South African 
conditions. This will ultimately have a huge implication on food and nutritional security in the country.

\section{Materials and Methods}

\section{Plant materials}

The 22 cowpea genotypes which originated from Nigeria and South Africa were obtained from the gene bank of Agricultural Research Council (ARC), South Africa. The genotypes were selected based on their pod morphological characteristics. Field experiments were conducted at the ARC, Roodeplaat $\left(25.604^{\circ} \mathrm{S}, 28.345^{\circ} \mathrm{E}\right)$ in the 2013 and 2014 summer cropping seasons. The genotypes were evaluated in a field that was laid out in a randomized complete block design with three replications. The fresh and immature pods of the genotypes were harvested and analysed for total protein content and selected mineral elements (calcium, copper, iron, potassium, magnesium, manganese, sodium, phosphorus, aluminium, boron and zinc) at the Soil, Climate and Water (SCW) analytical laboratory of the ARC.

\section{Protein analysis}

A dry oxidation (Dumas) method was used to determine the total nitrogen and the crude protein contents $(\mathrm{N} \times 6.25)$ (Matejovic, 1995; Jimenez and Ladha, 1993) of the samples.

\section{Mineral analysis}

$\mathrm{K}^{+}, \mathrm{Ca}^{2+}, \mathrm{P}^{3-}, \mathrm{Mg}^{2+}, \mathrm{Na}^{+}, \mathrm{Fe}^{2+}, \mathrm{Mn}^{2+}, \mathrm{B}^{3+}, \mathrm{Al}^{3+}, \mathrm{Zn}^{2+}$ and $\mathrm{Cu}^{+}$ contents in the samples of immature pods were determined using the Inductively Coupled Plasma Optical Emission Spectrometric method (Zasoski and Burau, 1977).

\section{Statistical data analysis}

The analysis was carried out in triplicate for the determination of mineral elements and total protein contents and the results of the triplicates were expressed as a mean. Agronomix (2008) computer software was used for the Analysis of Variance (ANOVA). The differences in means were compared using the least significance difference. Genetic parameters were estimated from ANOVA mean square to determine genetic variability among the genotypes, as well as the genetic effect on different characteristics using the functions suggested by Uguru (1995):

Genetic variance $\left(\sigma^{2} \mathrm{~g}\right)=\mathrm{MSg}-\mathrm{MSe} / \mathrm{r}$, where MSg $=$ Mean squares of genotype; $\mathrm{MSe}=$ Mean squares of error; $r=$ number of replications.

Phenotypic variance $\left(\sigma^{2} p\right)=\sigma^{2} g+$ MSe

Genotypic coefficient of variation $(\mathrm{GCV})=(\sqrt{\mathrm{Vg}} / \mathrm{X}) 100$, and, Phenotypic coefficient of variation $(\mathrm{PCV})=$ $(\sqrt{ } \mathrm{V} p / \mathrm{X}) 100$, where $\mathrm{X}$ is the grand mean for the phenotypic traits.

Broad sense heritability $\left(h^{2} b s\right)=\left(\sigma^{2} g / \sigma^{2} p\right) \times 100$

Data was also subjected to multivariate analysis using the appropriate procedure of the Number Cruncher Statistical System (NCSS, 2004). Principal component analysis (PCA) was used as a data reduction tool to summarise the information from the data set so that the influence of noise and outliers on the clustering results is reduced. The first two principal component axes were used to graphically produce two-dimensional scatter plots to visualize the similarity and the differences evaluated for the mineral elements and protein contents in the immature pods of cowpeas.

\section{Conclusion}

Immature green pods of cowpea are an important source of protein and essential micro and macro-elements. The existence of wide genetic variability among the 22 cowpea genotypes in terms of mineral elements and total protein content in their green and immature pods, as revealed in this study, will assist in the selection of genotypes that can be used as parents when breeding for the improvement of nutritional quality in cowpea in South Africa. This would also increase the frequency of the favourable genes/alleles and genetic recombination of the traits/genes of interest. The following cowpea genotypes that were identified as potential good parents that will be incorporated into the cowpea nutritional quality improvement programme in South Africa are: $98 \mathrm{~K}-5301\left(\mathrm{k}^{+}, \mathrm{Ca}^{2+}, \mathrm{P}^{3-}\right.$ and protein), ITOOK-1060 $\left(\mathrm{Mg}^{2+}, \mathrm{Na}^{+}, \mathrm{Mn}^{2+}, \mathrm{B}^{3+}, \mathrm{Al}^{3+}\right.$ and $\left.\mathrm{Zn}^{2+}\right)$, IT845-2246 $(\mathrm{Cu})$ and TVU-14196 $\left(\mathrm{Fe}^{2+}\right)$. Results of this study, therefore, will have a positive impact on food and nutritional security in South Africa.

\section{Acknowledgement}

The authors would like to acknowledge the Agricultural Research Council (ARC) for the financial support and the ARC-Grain Crops Institute for providing the cowpea genotypes for the study.

\section{References}

Agronomix (2008) Agrobase Generation II. Agronomix Software, Inc. 71 Waterlo St. Winnipeg, Manitoba, R3N054, Canada.

Ahenkora K, Adu-Dapaah HK, Agyemang A (1998) Selected nutritional components and Sensory attributes of cowpea (Vigna unguiculata [L.] Walp.) leaves. PlantFoodsHum Nutr. 52:221-229.

Akinwale RO, Obisesan IO (2012) Collection and characterization of some underutilized cowpea (Vigna Unguiculata L.) cultivars of South Western Nigeria. J Sustain Dev Environ Protect. 2: 37-47.

Amany MS, Hoda IM (2016) Morphological, physiological and chemical traits of some forage cowpea genotypes. American-Eurasian J Agric Environ Sci. 16: 302-311.

Ano OA, Ubochi CI (2008) Nutrient composition of climbing and prostrate vegetable cowpea accession. Afr $\mathrm{J}$ Biotechnol. 7: 3795-3798.

Arinola OG (2008) Essential trace elements and metal binding proteins in Nigerian consumers of alcoholic beverages. Pak J Nutr. 7: 763-765.

Bhat R, Karim, AA (2009) Exploring the nutritional potential of wild and underutilized legumes. Compr Rev Food Sci Food Safe. 8: 305-331.

Branca F, Ferrari M (2002) Impact of micronutrient deficiency on growth: the stunting syndrome. Ann Nutr Metab. 46: 8-17.

Duke JA (1981) Vigna unguiculata (L.) Walp. ssp. unguiculata. In: Handbook of Legumes of world economic importance. Plenum Press, New York.

FAO (2006) Food and Agriculture Organization, State of Food Insecurity in the World. Food and Agricultural Organisation, Rome, Italy.

Gerrano AS, Adebola PO, Rensburg WS, Venter SL (2015) Genetic variability and heritability estimates of nutritional composition in the leaves of selected cowpea genotypes [Vigna unguiculata (L.) Walp.]. HortSci. 50: 1435-1440. 
Hall EA, Cissé N, Thiaw S, Elawad HOA, Ehlers JD, Ismail AM, Fery RL, Roberts PA, Kitch LW, Murdock LL, Boukar O, Phillips RD, Mc Watters KH (2003) Development of cowpea cultivars and germplasm by the Bean/Cowpea CRSP. Field Crops Res. 82: 103-134.

Hazra P, Chattopadhaya A, Dasgupta T, Kar N, Das PK, Som MG (2007) Breeding strategy for improving plant type, pod yield and protein content in vegetable cowpea (Vigna unguiculata). Acta Hort. 752: 275-280.

Hazra P, Chattopadhyay A, Dasgupta T, Som MG (2001) Bidhan Barbati-1 and Bidhan Barbati-2: New high yielding and non-viny vegetable cowpeas. Indian Hort. 46:13-15.

Jimenez RR, Ladha JK (1993) Automated elemental analysis: A rapid and reliable but expensive measurement of total carbon and nitrogen in plant andsoil samples. Commun Soil Sci Plant Anal. 24: 1897-1924.

Madode YE, Linnemann AR, Nout MJR, Vosman B, Hounhouigan, DJ, van Boekel MAJ (2012) Nutrients, technological properties and genetic relationships among twenty cowpea landraces cultivated in West Africa. Int J Food Sci Technol. 2012, 1-12.

Matejovic I (1995) Total nitrogen in plant material determined by means of dry combustion: Apossible alternative to determination by Kjeldahl digestion". Commun Soil Sci Plant Anal. 26: 2217-2229.

Mobina P, Narayan CC, Jagatpati T (2014) Strategy of biometric evaluation of vegetative yield attributes of Amaranth cultivars. Biodiscovery. 5:70-73.

Murray RK, Granner DK, Mayes PA, Rodwell VW (2000) Harper's Biochemistry, $25^{\text {th }}$ Edition, McGraw-Hill, Health Profession Division, USA.

NCSS (2004) Number Cruncher Statistical Systems, Dr. Jerry L. Hintze, 329 North 1000 East, Kaysville, Utah 84037, Canada.

Nielsen SS, Ohler TA, Mitchell CA (1997) Cowpea leaves for human consumption: production, utilization, and nutrient composition. In: Singh BB, Mohan Raj DR,Dashiell KE, Jackai LEN (eds) Advances in Cowpea Research. Co-publication Intl Inst Tropical Agric (IITA) and Japan Intl Res Center Agric Sci (JIRCAS). Sayce, Devon, UK, pp. 326-332.

Noubissié TJB, Bell JM, Nassourou1 AM, Njintang YN, Youmbi E (2011) Genetic analysis of seed proteins contents in cowpea (Vigna unguiculata L. Walp.) Afr J Biotechnol. 10:3077-3086.

Ojimelukwe PC, Nwofia GE, Nnadi O (2014) Comparison of the nutrient composition and physical characteristics of nigerian local vegetable cowpea varieties (Vigna unguiculata Walp.) and exotic ones. Int J Curr Res. 6: 4873-4876.

Phillips RD, McWatters KM (1991) Contribution of cowpeas to nutrition and health. Food Technol. 45: 127-130.

Ramakrishnan U, Manjrekar R, Rivera J, Gonzales-Cossio T, Martorell R (1999) Micronutrients and pregnancy outcome: a review of the literature. Nutr Res. 19: 103-159.

Rangel A, Domont GB, Pedrosa C, Ferreira ST (2003) Functional properties of purified vicilins from cowpea (Vigna unguiculata) and pea (Pisum sativum) and cowpea protein isolate. J Agric Food Chem. 51: 5792-5797.

Reynolds AP, Kiely E, Meadows N (1994) Manganese in long term paediatric parenteral nutrition. Arch Dis Child. 71:527-528

Shegro A, Shargie NG, van Biljon A, Labuschagne MT (2012) Diversity in starch, protein and mineral composition of sorghum landrace accessions from Ethiopia. J Crop Sci Biotechnol. 15: 275- 280.
Singh BB, Ajeigbe HA, Tarawali SA, Fernandez-Rivera S, Abubakar M (2003) Improving the production and utilization of cowpea as food and fodder. Field Crops Res. 84: 169- 177

Shukla SA, Bhargava A, Chatterjee J, Srivastava N, Singh and Singh SP (2006) Mineral profile and variability in vegetable amaranth (Amaranthus tricolor). Plant Foods Hum Nutr. 61:23-28.

Timko MP, Singh BB (2008) Cowpea, a multifunctional legume. In: Moore PH, Ming R (eds.) Genomics of tropical crop plants, department of biology, University of Virginia, Charlottesville, VA 22904 USA, pp. 227-258.

Ubi E, Mignouna H, Obigbesan G (2001) Segregation of seed weight, pod length and days to flowering. Afr J Crop Sci. 9: 463-470.

Uguru MI (1995) Heritable relationships and variability of yield and yield components invegetable Cowpea. Afr J Crop Sci. 3: 23-28.

Van Gossum A, Neve J (1998) Trace element deficiency and toxicity. Curr Opin Clin Nutr Metab Care J. 1:499-507.

Vaughan JG, Geissler CA (2008) The new oxford book of food plants. Oxford University Press Inc., pp. 52.

Welch RM, Graham RD (2004) Breeding for micronutrients in staple food crops from a human nutrition perspective. $\mathrm{J}$ Exp Bot. 55: 353-364.

Welch RM, Johansen C (2002) Combining genetic improvement with natural resource management. In: AduGyamfi, JJ (ed.) Food security in nutrient-stressed environment: exploiting plants' genetic capabilities. Kluwer academic publishers, Dordrecht, Netherlands pp. 331-335.

WHO (2006) World Health Organization, Nutrition for Health and Development.http://www.who.int/nutrition/ challenges/en/index.html, accessed on 29 March 2016.

Yusuf CS, Moses J, Atijegbe RM (2013) The nutritional composition young pods of the Moringa Oleifera (Lam) and green beans (Vigna Unguiculata (L) Walp) in Mubi,

Zasoski RJ, Burau RG (1977) A Rapid Nitric-Perchloric Acid digestion method for multi-element tissue analysis. Commun Soil Sci Plant Anal. 8: 425-436.

Zlotkin SH, Buchanan BE (1988) Amino acid intake and urinary zinc excretion in new born infants receiving total parenteral nutrition. Am J Clin Nutr. 48: 330-334. 